\title{
Inorganic Elements in Eggs of Two Cavity-Nesting Passerine Species at and around Los Alamos National Laboratory, Los Alamos, New Mexico
}

\author{
Shannon Marie Gaukler ${ }^{1 *}$, Charles Dean Hathcock ${ }^{1}$, Jeanne Marie Fair ${ }^{2}$ \\ ${ }^{1}$ Environmental Stewardship Group, Los Alamos National Laboratory, Los Alamos, NM, USA \\ ${ }^{2}$ Biosecurity and Public Health, Los Alamos National Laboratory, Los Alamos, NM, USA \\ Email: *sgaukler@lanl.gov
}

How to cite this paper: Gaukler, S.M., Hathcock, C.D. and Fair, J.M. (2018) Inorganic Elements in Eggs of Two CavityNesting Passerine Species at and around Los Alamos National Laboratory, Los Alamos, New Mexico. Journal of Environmental Protection, 9, 932-947.

https://doi.org/10.4236/jep.2018.99058

Received: June 21, 2018

Accepted: August 11, 2018

Published: August 14, 2018

Copyright (c) 2018 by authors and Scientific Research Publishing Inc. This work is licensed under the Creative Commons Attribution International License (CC BY 4.0).

http://creativecommons.org/licenses/by/4.0/

\begin{abstract}
Los Alamos National Laboratory (LANL) was established in 1943 as part of the Manhattan Project to build nuclear weapons, and currently operates as a national research laboratory. As part of an ongoing assessment of site-related ecological risk at LANL, western bluebird (Sialia mexicana) and ash-throated flycatcher (Myiarchus cinerascens) eggs were collected from 1997 to 2012 and analyzed for 18 inorganic elements. Concentrations of many inorganic elements in eggs were below reporting limits. Between species comparisons revealed that western bluebird eggs had higher levels of barium while ash-throated flycatcher eggs had higher levels of mercury. No statistically significant differences were observed in concentrations of inorganic elements in western bluebird eggs collected from the study area (which consists of areas within the current and historic LANL boundary) and from a non-industrial reference site; nor were any statistically significant differences observed between two canyons of interest, known to have received effluents and storm water runoff from LANL facilities, and the non-industrial reference site. Inorganic element levels detected in western bluebirds were typically within the range measured in eggs of other passerine in the published literature. These data suggest that concentrations of inorganic elements in passerine eggs collected from the study area appear to be at levels causing negligible risks to local bird populations.
\end{abstract}

\section{Keywords}

Ash-Throated Flycatcher, Biomonitoring, Metals, Western Bluebird 


\section{Introduction}

Los Alamos National Laboratory (LANL) is located on the Pajarito Plateau in Northern New Mexico and was established in 1943 as part of the Manhattan Project with the primary goal of designing and building nuclear weapons (Figure 1). Currently, a wide variety of research programs directly and indirectly support LANL's mission of solving national security challenges. Early waste disposal practices and operations during decades of science and technology development resulted in releases of inorganic elements into the environment. Release sites include numerous point sources such as firing sites, industrial and sanitary outfalls, landfills, and storage areas [1] [2] [3]. Assessing site-related ecological risk is especially challenging because LANL operations cover a large area (approximately $104 \mathrm{~km}^{2}$ ) and there are multiple release types and locations.

Some canyons at LANL received effluents from facility outfalls, and also may receive storm water runoff from developed areas and solid waste storage units (areas containing solid waste) as well as runoff from undeveloped areas. Canyons of interest in this study include Cañada del Buey and Mortandad (Figure 1). Sections of both Cañada del Buey and Mortandad Canyon are currently part of LANL. Historic release sites along Cañada del Buey include various outfalls, an inactive septic system, and a disposal area for low-level radioactive waste [4]. Historic release sites along Mortandad Canyon include outfalls, sanitary septic systems, and discharges from a wastewater treatment plant [5]. Several constituents are of interest in these canyons, including inorganic elements [6] [7] [8].

Biomonitoring is an important tool for assessing environmental contamination by analyzing chemicals or their metabolites from biological tissues [9] [10]. Bird eggs are useful as bioindicators because 1) different species occupy many trophic levels, 2) collection of eggs is relatively noninvasive and nondestructive to populations, and 3) collection is relatively easy. In addition, the composition of eggs is consistent and eggs can be preserved for long periods of time for inorganic element analyses [9] [11] [12]. Studies suggest that avian eggs reflect local contaminant exposure where the female was feeding during the time of egg formation [13], however, migratory species may also accumulate constituents during migration or on wintering grounds [14] [15] [16].

Inorganic elements can pose risks of adverse effects to birds if exposed at high enough concentrations. For example, mercury and selenium egg exposures have been associated with deleterious effects on reproduction, growth, survival, and behavior in birds [17] [18] [19]. Sources of inorganic elements include both anthropogenic and natural sources [1] and birds can be exposed through a number of routes including through diet, ingestion of soil, drinking water, and inhalation. Once a bird is exposed to inorganic elements, those elements may be absorbed and deposited into tissues. Alternatively, they may be excreted or sequestered into feathers [20]. Female birds may also excrete contaminant body burdens into their eggs; therefore, eggs serve as a potential indicator of internal contamination loads of the adult female [10] [20] and have been utilized as metal 
pollution bioindicators in several studies [21] [22] [23] [24]. Inorganic element levels in eggs can provide insight on whether ultimate-level functions, such as reproduction and survival may be impaired due to exposure to these constituents.

The western bluebird (Sialia mexicana) and the ash-throated flycatcher (Myiarchus cinerascens) are common secondary cavity-nesting species on the Pajarito Plateau [25] and readily nest in artificial nestboxes. Ash-throated flycatchers are a migratory species and their winter range spans from Mexico to Costa Rica [26]. Western bluebirds are year-round residents in many areas, including northern New Mexico, although some migration into Mexico may occur [27]. During the breeding season, both species feed primarily insects, including ants, wasps, and beetles, as well as spiders [27] [28]. Both species rely on fruits during the winter and western bluebirds also consume seeds [27] [29]. Western bluebirds have also been observed picking up small amounts of grit for their gizzards [30]. These two species have several similar life history traits, although ash-throated flycatchers have approximately $22 \%$ higher daily energetic demand (i.e., higher metabolism) and their nestlings fledge approximately four to five days earlier than western bluebirds [31].

As part of an ongoing assessment of site-related ecological risk at LANL [32], inorganic element concentrations were assessed in western bluebird and ashthroated flycatcher eggs. In experiment one, we evaluate concentrations of inorganic elements in eggs of western bluebirds and ash-throated flycatchers and predict that ash-throated flycatchers will have differing concentrations of inorganic elements due to their migratory behavior. In experiment two, we evaluate concentrations of inorganic elements in western bluebird eggs across the Pajarito Plateau and predict that eggs collected within the current and historic LANL boundary will have higher concentrations than those collected at a non-industrial reference site; and that eggs collected from two canyons of interest, Cañada del Buey and Mortandad Canyon, will have higher concentrations than those collected at the reference site. Lastly, we compare the concentrations in eggs from experiment two with concentrations observed in eggs of other passerine species reported in the literature and predict that the majority of eggs will fall within the range observed in other species.

\section{Methods}

\subsection{Study Location}

LANL is situated on the Pajarito Plateau in Los Alamos and Santa Fe counties of north-central New Mexico (Figure 1). The Pajarito Plateau consists of a series of narrow mesa tops and deep canyons and was formed by the eruptions of Valles and Toledo volcanos, which occurred 1.4 and 1.1 million years ago. The region where the study took place has a southeastern drainage and includes a large elevation gradient, ranging from approximately 1890 to $2400 \mathrm{~m}$ spanning from the Rio Grande to the Jemez Mountains. Los Alamos County has a temperate mountain climate, four distinct seasons, an annual average temperature range of 


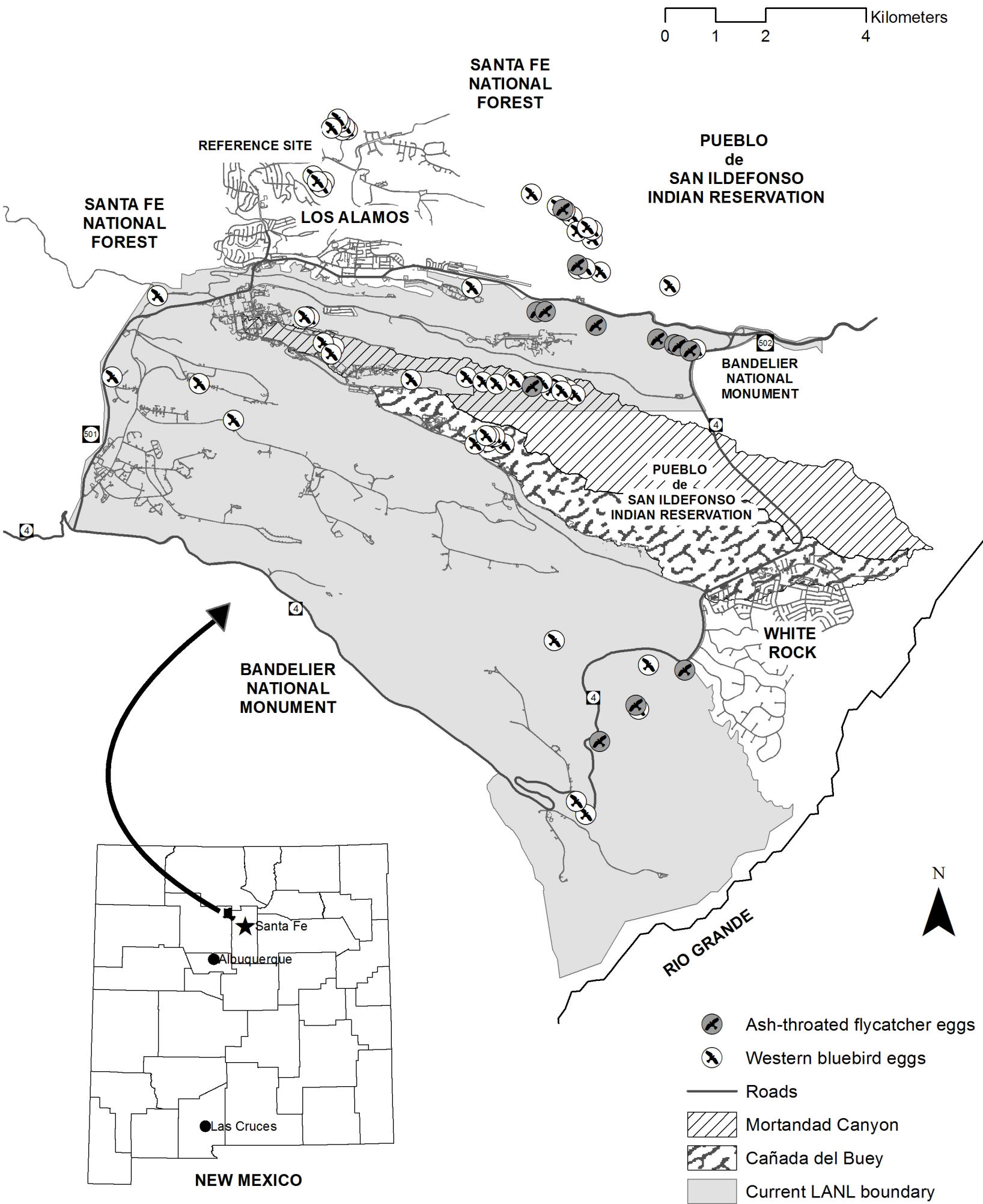

Figure 1. Study region showing where western bluebird and ash-throated eggs that underwent analysis for inorganic elements were collected. Weighted geometric means were used to represent composite samples (i.e., eggs collected from multiple nestboxes). The study area includes locations within and around current and historic boundaries of Los Alamos National Laboratory, including both canyons of interest; the non-industrial reference site consists of the cemetery and golf course located upgradient of Los Alamos National Laboratory in the Los Alamos townsite. Samples were collected between 1997 and 2012. Figure was created using ArcGIS 10.3.1 (ESRI, Redlands, California). 
$2.7^{\circ} \mathrm{C}$ to $15.5^{\circ} \mathrm{C}$, and an average annual precipitation of $47.9 \mathrm{~cm}$ [33]. Vegetation types on the Pajarito Plateau are predominantly piñon-juniper woodland (Pinus edulis-Juniperus monosperma) and ponderosa pine forest (Pinus ponderosa) mixed with Gambel oak (Quercus gambelii); however, many vegetation classes have been identified in the study area and include riparian species such as willows (Salix spp.) and cottonwoods (Populus spp.), grasslands, shrublands, sagebrush grassland, piñon grassland, juniper grassland, juniper savanna, piñon-juniper woodland, ponderosa pine forest, mixed conifer forest, spruce-fir forest (Picea engelmannii-Abies lasiocarpa), and aspen (Populus tremuloides) communities [34].

\subsection{Nestboxes and Egg Collection}

The avian nestbox network was established during the winter of 1997 with 438 boxes [35] and now contains more than 500 boxes. The majority of nestboxes were placed on ponderosa pine, piñon pine, or one-seed juniper trees, hung approximately $1 \mathrm{~m}$ off the ground and placed approximately 50 to $75 \mathrm{~m}$ apart within areas of interest (e.g., reaches of a canyon or clusters on a mesa top). Within the study area (which consists of areas within the current and historic LANL boundary), nestboxes were placed within the current LANL boundary or north of it where historical operations took place. Nestbox placements within the study area included the canyons of interest (Figure 1). To obtain reference values at a developed but non-industrial site, nestboxes were placed approximately $3 \mathrm{~km}$ upgradient of the study area in the Los Alamos townsite at a golf course and a cemetery (Figure 1).

Field crews began nestbox visits began each May and continued throughout the breeding season. Unhatched eggs were collected from nestboxes when nestlings in the same nest were $\geq 10$ days old or when an entire clutch was abandoned. During the breeding season of 2005 only, one potentially viable egg was randomly collected from 30 nests for a special study. Upon collection, eggs were refrigerated $\left(\sim 1.6^{\circ} \mathrm{C}-3.3^{\circ} \mathrm{C}\right)$ until processed. Eggs were then rinsed, patted and air dried, and measurements on weight, volume, length, and width were collected. After measurements were recorded, egg contents were separated from eggshells, stored in sealed glass vials and kept frozen until shipped to the analytical chemistry laboratory. Moisture loss from eggs during storage was considered as a confounding variable. However, as egg moisture is lost, it results in higher measurements of element concentrations, which is a conservative error. Egg content samples were submitted as either an individual egg, or eggs were combined to form a composite sample; eggs were only composited from the same location (i.e., same reaches of a canyon). All protocols were approved by the LANL Institutional Animal Care and Use Committee and unhatched egg collection was permitted under federal and state permits.

\subsection{Chemical Analyses}

For experiment one, western bluebird and ash-throated flycatcher eggs were col- 
lected from 1997 to 2002 and were analyzed for inorganic elements in 2002 by the Illinois Waste Management and Research Center, Champaign, Illinois. There were 21 western bluebird samples ( $n=21$ individual eggs) and 13 ash-throated flycatcher samples ( $n=10$ individual egg samples, $n=3$ composite samples of two to four eggs). Mercury concentrations were measured by atomic fluorescence while the remaining inorganic elements (listed below) were measured by inductively coupled plasma-mass spectrometry (ICP-MS). Reporting limits (practical quantitation limit or $\mathrm{PQL}$ ) were 0.004 parts per million (ppm) for mercury; $0.1 \mathrm{ppm}$ for antimony, arsenic, barium, cadmium, copper, lead, manganese, and silver; and $1.0 \mathrm{ppm}$ for chromium, nickel, selenium, and zinc. All results are reported on a wet weight (ww) basis.

For experiment two, 50 western bluebird egg samples ( $n=34$ individual egg samples, $n=16$ composite samples of 2 to 28 eggs) were collected from 1998 to 2012 and were analyzed for inorganic elements (listed below) in 2005, 2008, and 2014 by ALS (Australian Laboratory Services, formerly Paragon Analytics, Inc.), Fort Collins, Colorado. Antimony, arsenic, cadmium, lead, selenium, and silver concentrations were measured by ICP-MS (EPA SW-846:6020) and barium, beryllium, chromium, cobalt, copper, iron, manganese, nickel, vanadium, and zinc were measured by inductively coupled plasma-atomic emission spectrometry (EPA SW-846:6010B). Mercury was measured by cold-vapor atomic absorption procedure (EPA SW-846:7471A). The lowest reporting limit (PQL) was 0.001 ppm for silver; $0.002 \mathrm{ppm}$ for thallium; $0.003 \mathrm{ppm}$ for antimony, cadmium, and mercury; $0.005 \mathrm{ppm}$ for lead; $0.01 \mathrm{ppm}$ for beryllium and selenium; $0.02 \mathrm{ppm}$ for arsenic, barium, cobalt, copper, and manganese; $0.05 \mathrm{ppm}$ for chromium, nickel, vanadium, and zinc; and $0.5 \mathrm{ppm}$ for iron. All results are reported on a wet weight (ww) basis.

\subsection{Comparisons with Other Passerine Species}

For experiment two, published studies were used to make comparisons of inorganic element concentrations in passerine eggs. The data in the studies used date back as far as 1995 to better overlap the time period with the current study [11] [21] [22] [23] [24] [36]-[43]. Species from other studies include Bell's vireo (Vireo bellii), black-throated gray warbler (Setophaga nigrescens), blue tit (Cyanistes caeruleus), brown-headed cowbird (Molothrus ater), Carolina wren (Thryothorus ludovicianus), common yellowthroat (Geothlypis trichas), Florida-scrub jay (Aphelocoma coerulescens), great tit (Parus major), house sparrow (Passer domesticus), house wren (Troglodytes aedon), lesser goldfinch (Spinus psaltria), marsh wren (Cistothorus palustris), red-winged blackbird (Agelaius phoeniceus), song sparrow (Melospiza melodia), summer tanager (Piranga rubra), tree swallow (Tachycineta bicolor), vermilion flycatcher (Pyrocephalus rubinus), southwestern willow flycatcher (Empidonax traillii extimus), yellow warbler (Setophaga petechia), and yellow-breasted chat (Icteria virens). When studies compared a contaminated site to a reference site, a con- 
servative approach was used and only the values from their reference sites were included. When PQLs from the ALS laboratory exceeded the maximum concentration observed in other passerine species, comparisons with eggs from the current study were excluded. Means and $99 \%$ confidence intervals were calculated for passerines in published studies and the percentage of nondetects and samples at or below the upper confidence level from this study are reported.

\subsection{Statistical Analysis}

Prior to statistical analyses, all nondetect values were reported at the reporting limit (PQL) and nondetect samples associated with a blank contamination were excluded from analyses ( $n=7$ samples for iron analyses and $n=6$ for manganese analyses). Elements did not undergo statistical analyses when $80 \%$ or more of the samples were nondetects for a given analyte [44]. For remaining datasets containing nondetect values, comparisons between two or more groups were assessed with the Gehan-Wilcoxon test [45], which included assessing differences in concentrations between species, between the study area and the non-industrial reference site, and among two canyons and the non-industrial reference site. For datasets that did not contain nondetect values, a Wilcoxon test was used to assess differences between species and between the study area and the non-industrial reference site. The Kruskal-Wallis test was used to analyze for differences among two canyons and the non-industrial reference site for datasets which contained no nondetects. All statistical analyses were performed using NCSS 9 Statistical Software 2013 (Kaysville, Utah).

\section{Results}

In experiment one, only barium, copper, manganese, mercury, and zinc were detected in $20 \%$ or more of egg samples and were therefore statistically analyzed. In experiment two, only barium, copper, iron, manganese, mercury, selenium, and zinc were detected in $20 \%$ or more of egg samples and were therefore statistically analyzed. Antimony, arsenic, beryllium, cadmium, chromium, cobalt, lead, nickel, silver, thallium, and vanadium were frequently $(\geq 80 \%)$ not detected in eggs in at least one variable (i.e. one species or one site such as the study area or non-industrial reference site) for both experiments; therefore these elements were not subjected to statistical analyses.

Experiment 1: comparisons between western bluebirds and ash-throated flycatchers

Copper, manganese, and zinc concentrations did not differ significantly in eggs between species $(P>0.05$; Table 1$)$. Western bluebird eggs, however, contained approximately 6 times more barium (median concentration $2.34 \mathrm{ppm}$ ) than ash-throated flycatcher eggs (median concentration 0.38 ppm; $P<0.001$; Table 1). Ash-throated flycatcher eggs contained, 2.8 times more mercury (median concentration $0.11 \mathrm{ppm}$ ) when compared with western bluebird eggs (median concentration $0.04 \mathrm{ppm} ; P=0.02$; Table 1 ). 
Experiment 2: study area western bluebird eggs versus the reference site

Barium, copper, iron, manganese, mercury, selenium, and zinc concentrations were analyzed in western bluebird eggs from the study area and the non-industrial reference site and no statistically significant differences were observed $(P>0.05$; Table 2). For medians and range of observations between the two sites, see Table 2 .

Experiment 2: western bluebird eggs comparisons among two canyons and the reference site

Cañada del Buey, Lower Mortandad Canyon, and the non-industrial reference site were assessed for differences in the concentrations of inorganic elements in western bluebird eggs. No statistically significant differences were observed in concentrations of barium, copper, iron, manganese, mercury, selenium, or zinc among the three locations $(P>0.05$; Table 3$)$. For medians and range of observations, see Table 3 .

Experiment 2: comparisons with other passerine species

The majority $(\geq 50 \%)$ of western bluebird samples from both the non-industrial reference area and study area contained levels of inorganic elements that were within the range of concentrations observed in other passerine species in

Table 1. Inorganic element levels (ppm wet weight) in western bluebird eggs (Obs = observations) compared with ash-throated flycatcher eggs collected from the study area. For datasets containing nondetect (ND) values, comparisons between species were evaluated with a Gehan-Wilcoxon test. The remaining comparisons between species were examined with a Wilcoxon test.

\begin{tabular}{|c|c|c|c|c|c|c|c|c|c|}
\hline \multirow{2}{*}{ Element } & \multicolumn{4}{|c|}{ Western bluebird eggs } & \multicolumn{4}{|c|}{ Ash-throated flycatcher eggs } & \multirow{2}{*}{$P$} \\
\hline & Obs & $\% \mathrm{ND}$ & Median & Min-Max & Obs & $\% \mathrm{ND}$ & Median & Min-Max & \\
\hline Barium & 21 & 0 & 2.34 & $0.78-9.19$ & 13 & 0 & 0.38 & $0.11-2.86$ & $<0.001$ \\
\hline Copper & 21 & 0 & 1.86 & $0.50-4.45$ & 13 & 0 & 1.67 & $1.17-4.84$ & 0.94 \\
\hline Manganese & 18 & 14.3 & 0.58 & ND - 2.75 & 13 & 0 & 0.53 & $0.18-6.24$ & 0.60 \\
\hline Mercury & 21 & 0 & 0.04 & $0.01-0.51$ & 13 & 0 & 0.11 & $0.02-0.30$ & 0.02 \\
\hline Zinc & 21 & 0 & 12.3 & $5.87-55.97$ & 13 & 0 & 11.2 & $6.06-43.13$ & 0.80 \\
\hline
\end{tabular}

Table 2. Inorganic element levels (ppm wet weight) in western bluebird eggs (Obs = observations) collected from the study area compared with the non-industrial reference site. For datasets containing nondetect (ND) values, comparisons between sites were evaluated with a Gehan-Wilcoxon test. The remaining comparisons between sites were examined with a Wilcoxon test.

\begin{tabular}{|c|c|c|c|c|c|c|c|c|c|}
\hline \multirow{2}{*}{ Element } & \multicolumn{4}{|c|}{ Non-industrial Reference Site } & \multicolumn{4}{|c|}{ Study Area } & \multirow{2}{*}{$P$} \\
\hline & Obs & $\% \mathrm{ND}$ & Median & Min-Max & Obs & $\% \mathrm{ND}$ & Median & Min-Max & \\
\hline Barium & 15 & 0 & 1.30 & $0.55-5.30$ & 35 & 0 & 1.80 & $0.59-6.4$ & 0.50 \\
\hline Copper & 15 & 0 & 0.48 & $0.38-1.1$ & 35 & 0 & 0.66 & $0.24-23.0$ & 0.07 \\
\hline Iron & 14 & 0 & 34.0 & $20.0-77.0$ & 30 & 0 & 33.0 & $9.3-650.0$ & 0.70 \\
\hline Manganese & 14 & 0 & 0.67 & $0.33-1.5$ & 32 & 3.1 & 0.60 & ND - 51.0 & 0.73 \\
\hline Mercury & 9 & 11.1 & 0.016 & ND - 0.02 & 24 & 12.5 & 0.016 & ND - 0.08 & 0.90 \\
\hline Selenium & 15 & 0 & 0.45 & $0.3-1.2$ & 35 & 2.9 & 0.50 & $\mathrm{ND}-1.5$ & 0.28 \\
\hline Zinc & 15 & 0 & 12.0 & $7.3-30.0$ & 35 & 0 & 13.0 & $3.2-110.0$ & 0.84 \\
\hline
\end{tabular}


Table 3. Inorganic element levels (ppm wet weight) in western bluebird eggs (Obs = observations) collected from two canyons and the non-industrial reference site. For datasets containing nondetect (ND) values, comparisons among sites were evaluated with a Gehan-Wilcoxon test. The remaining comparisons among sites were examined with a Kruskal-Wallis test.

\begin{tabular}{cccccccccccccc}
\hline & \multicolumn{3}{c}{ Non-industrial Reference Site } & \multicolumn{4}{c}{ Cañada del Buey } & \multicolumn{3}{c}{ Lower Mortandad Canyon } \\
\cline { 2 - 11 } & Obs & \% ND & Median & Min-Max & Obs & \% ND & Median & Min-Max & Obs & \% ND & Median & Min-Max & $P$ \\
\hline Barium & 15 & 0 & 1.30 & $0.55-5.30$ & 6 & 0 & 2.65 & $0.59-3.70$ & 16 & 0 & 1.45 & $0.86-6.4$ & 0.67 \\
Copper & 15 & 0 & 0.48 & $0.38-1.1$ & 6 & 0 & 0.55 & $0.37-0.86$ & 16 & 0 & 0.65 & $0.35-23.0$ & 0.14 \\
Iron & 14 & 0 & 34.0 & $20.0-77.0$ & 6 & 0 & 27.5 & $23.0-38.0$ & 16 & 0 & 29.5 & $16.0-650$ & 0.49 \\
Manganese & 15 & 0 & 0.67 & $0.33-1.5$ & 6 & 0 & 0.68 & $0.44-1.40$ & 14 & 0 & 0.60 & $0.25-51.0$ & 0.82 \\
Mercury & 9 & 11.1 & 0.016 & ND - 0.02 & 5 & 0 & 0.011 & $0.01-0.01$ & 11 & 27.3 & 0.013 & ND - 0.02 & 0.42 \\
Selenium & 15 & 0 & 0.45 & $0.3-1.2$ & 6 & 0 & 0.41 & $0.35-0.59$ & 16 & 6.3 & 0.50 & ND - 0.85 & 0.64 \\
Zinc & 15 & 0 & 12.0 & $7.3-30.0$ & 6 & 0 & 12.5 & $11.0-15.0$ & 16 & 0 & 12.5 & $7.6-110.0$ & 0.98 \\
\hline
\end{tabular}

Table 4. The mean and $99 \%$ confidence interval (CI) of inorganic element concentrations observed in eggs of passerine species published in the literature and the percentage western bluebirds from the non-industrial reference site and study area that contain nondetectable concentrations or concentrations at or under the upper CI of other passerines. All values are reported as ppm wet weight; when dry weight were reported, they were converted by accounting for the average moisture content of $\sim 70 \%$ as suggested in Heinz et al. [57].

\begin{tabular}{|c|c|c|c|c|c|}
\hline Element & $\begin{array}{l}\text { Number of } \\
\text { Studies }\end{array}$ & $\begin{array}{l}\text { Number of } \\
\text { Species }\end{array}$ & $\begin{array}{l}\text { Mean }(99 \% \text { CI }) \\
\text { observed in } \\
\text { other species }\end{array}$ & $\begin{array}{l}\text { Percent nondetects and those at and under } \\
\text { the upper CI of other passerines (western } \\
\text { bluebird Non-industrial Reference Site) }\end{array}$ & $\begin{array}{l}\text { Percent nondetects and those at and } \\
\text { under the upper CI of other passerines } \\
\text { (western bluebird Study Area) }\end{array}$ \\
\hline Arsenic & 8 & 8 & $0.08(0.01,0.15)$ & 100 & 97.1 \\
\hline Barium & 4 & 13 & $1.32(0.66,1.98)$ & 60.0 & 54.3 \\
\hline Cobalt & 1 & 1 & $0.01(0.01,0.02)$ & 100 & 100 \\
\hline Copper & 8 & 17 & $1.02(0.66,1.38)$ & 100 & 94.3 \\
\hline Iron & 4 & 3 & $36.9(12.3,61.6)$ & 85.7 & 90.0 \\
\hline Lead & 7 & 9 & $0.24(0.10,0.39)$ & 100 & 94.3 \\
\hline Manganese & 7 & 15 & $0.79(0.51,1.07)$ & 78.6 & 77.4 \\
\hline Mercury & 9 & 7 & $0.06(0.02,0.10)$ & 100 & 100 \\
\hline Selenium & 7 & 15 & $0.86(0.68,1.04)$ & 93.3 & 91.4 \\
\hline Vanadium & 2 & 8 & $0.39(0.17,0.61)$ & 100 & 97.1 \\
\hline Zinc & 8 & 17 & $17.5(15.0,20.0)$ & 80.0 & 94.3 \\
\hline
\end{tabular}

published literature (Table 4). Western bluebird egg samples collected from the non-industrial reference area contained levels of arsenic, cobalt, copper, lead, mercury, and vanadium that were all within the range of other passerine species. Western bluebird egg samples collected from the study area contained cobalt and mercury concentrations were all within the range observed in other passerine species. Approximately $79 \%$ or more of western bluebird egg samples from the non-industrial reference area contained iron, manganese, selenium, and zinc concentrations, and $77 \%$ or more of the western bluebird eggs from the study are contained arsenic, copper, iron, lead, manganese, selenium, vanadium, and 
zinc concentrations within the range observed in other passerine species. However, only $60 \%$ of the western bluebird samples from the non-industrial reference area and 54\% from the study area contained barium concentrations that were within the range observed in other passerine species. In passerine species reported in the literature, all beryllium values were below the detection limits, and antimony and thallium were not reported; therefore no comparisons with concentrations in eggs from this study could be made. Reporting limits of cadmium, chromium, nickel, and silver in this study exceeded the maximum concentration observed in the published studies and therefore not compared.

\section{Discussion}

Many of the inorganic elements assessed in this study were not detected in egg samples of western bluebirds and ash-throated flycatchers. It has been proposed that some inorganic elements are not maternally transferred into eggs; for example, laboratory-controlled avian studies measured concentrations of cadmium [46] [47], lead [48], and vanadium [49] in eggs after females were provided diets with varying concentrations of these metals. These studies determined that little or no measurable amount of these metals were transferred to or accumulated in eggs. Additionally, Schwarzbach et al. [50] summarized data from Seiler and Skorupa [51] that reported on silver concentrations in more than 1000 wild bird eggs. Schwarzbach et al. [50] suggested that silver can, but rarely will, accumulate in avian eggs. Some of the inorganic elements assessed in this study may not have been maternally transferred to eggs by either the western bluebirds or the ash-throated flycatchers and may explain why so many inorganic elements were largely nondetects in eggs observed in this study.

1) Experiment 1: comparisons between western bluebirds and ash-throated flycatchers

Comparisons of inorganic element concentrations between species revealed that ash-throated flycatcher eggs had higher levels of mercury and western bluebird eggs contained higher levels of barium. Differences in diets, consumption of dirt as grit, metabolic rates, or exposures during the nonbreeding seasons between these two species may explain these observations. Some metals that are stored in the body become mobilized when a female begins to lay eggs [12]; therefore, mercury could have been ingested or picked up elsewhere, such as wintering grounds or off the study area. Since ash-throated flycatchers are migratory, perhaps a proportion of the inorganic elements observed here actually came from their wintering grounds that range from Mexico to Costa Rica [26]. The higher levels of barium in western bluebird eggs may also be explained by life history differences. Western bluebirds typically reside as year-round residents in many areas, including northern New Mexico [27] and evidence exists that western bluebirds are short distance migrants (unpublished data). Barium is higher in soils in the western United States [52] and is typically higher in soils that contain feldspar, limestone, and biotite [53]. The primary rock type in the 
study area is rhyolite [54], which is composed of feldspar (50\% - 70\%) and also contains biotite [55]. No differences of barium concentrations in soils collected at the study area compared with the reference site were observed [56]. It is possible that barium is naturally higher in soils around the study region and thus would explain why western bluebird eggs have greater concentrations of barium; especially because western bluebirds have been observed picking up grit for their gizzards [30]. This may also explain why there are no statistically significant differences in barium egg concentrations in western bluebird eggs collected at LANL and eggs collected from the non-industrial reference site.

2) Experiment 2: inorganic element concentrations in western bluebird eggs across the Pajarito Plateau

Contrary to our predictions, inorganic element concentrations in western bluebird eggs collected from the study area, which included areas from within the current and historic LANL boundary, did not differ from those collected from a non-industrial reference site. Additionally, no differences in western bluebird inorganic element egg concentration were observed among Cañada del Buey, Lower Mortandad Canyon, and the non-industrial reference site. These data suggest that LANL operations are not affecting inorganic element concentrations in eggs of western bluebirds, at least in the locations where this study took place.

3) Experiment 2: comparisons with other passerine species

As predicted, the majority of western bluebird egg samples contained either nondetectable concentrations of inorganic elements or contained concentrations that were at or fell under the upper 99\% confidence interval observed in other passerine species from reference sites reported in the literature. However, approximately $40 \%$ and $46 \%$ of western bluebirds at the non-industrial reference site and study area, respectively, exceeded the upper $99 \%$ confidence interval for barium that was established from other passerine species; this observation could be explained by the local geology as discussed above. Several factors could affect inorganic element concentrations in passerine eggs and include, but are not limited to, differences between species, diets, wintering and breeding grounds, soil type, and soil element concentrations. However, the comparisons made here are a general reference of how western bluebird eggs collected in study area compare with eggs of other passerine species. In general, concentrations of inorganic elements in eggs examined in this study are very similar to concentrations in eggs of other passerine species in undisturbed areas, even though some eggs were collected in disturbed areas within the study area.

\section{Conclusion}

This study is part of an ongoing assessment of site-related ecological risk at LANL and the constituents evaluated in eggs of two cavity-nesting species reveal that the majority of samples had concentrations that were below the reporting limit. Egg samples that had detectable levels of inorganic elements were typically 
at or below the upper $99 \%$ confidence interval concentration of those detected in other passerine species collected from a reference site. Additionally, no differences of inorganic element concentration in western bluebird eggs across the Pajarito Plateau were observed. The data presented here suggest that concentrations of inorganic elements in passerine eggs collected from within the current and historic LANL boundary appear to be at levels causing negligible risks to local bird populations.

\section{Acknowledgements}

We wish to thank P. Beeson, K. Burnett, K. Colestock, S. Cooper, J. Fox, L. Haussamen, A. Jacobs, M. Jankowski, L. Maestas, V. Mason, B. Pearson, R. Robinson, L. Reader, V. Seamster, S. Sherwood, T. Sommer, C. Talus, and S. Whitaker for the avian nestbox network operation and maintenance, data collection, and data entry; K. Burnett for literature review; and P. Fresquez, L. Hansen, T. Hiteman, and R. Mirenda for review. We also wish to thank K. Greene, N. Patel, and S. Marczak for analytical chemistry guidance and database assistance; and the sample management office, in particular K. Greene and S. Sherwood for care of samples. Finally, we wish to acknowledge and thank our funding sources: Los Alamos National Security, LLC, operator of the Los Alamos National Laboratory under US Department of Energy Contract No. DE-AC52-06NA25396. Los Alamos Unlimited Release number LA-UR-16-24852.

\section{Conflicts of Interest}

The authors declare no conflicts of interest regarding the publication of this paper.

\section{References}

[1] Ryti, A.T., Longmire, P.A., Broxton, D.E., Reneau, S.L. and Mcdonald, E. V. (1998) Inorganic and Radionuclide Background Data for Soils Canyon Sediments, and Bandelier Tuff at Los Alamos National Laboratroy. Los Alamos National Laboratory Report LA-UR-98-5054.

[2] Reid, K.D., Reneau, S.L., Newman, B.D. and Hickmott, D.D. (2005) Barium and High Explosives in a Semiarid Alluvial System, Cañon de Valle, New Mexico. Vadose Zone Journal, 4, 744. https://doi.org/10.2136/vzj2004.0174

[3] Travers, J., Alexandrova, E. and Resnikoff, M. (2009) An Assessment of Los Alamos National Laboratory Waste Disposal Inventory. Radioactive Wast Management Associates, New York.

[4] Reneau, S. (2000) Evaluation of Possible Sediment Contamination in the White Rock Land Transfer Parcel: Reach CDB-4. Los Alamos National Laboratory Report LA-UR-00-5071.

[5] LANL, Los Alamos National Laboratory (1997) Work Plan for Mortandad Canyon Environmental Restoration Project. Los Alamos National Laboratory Report LAUR-97-3291.

[6] LANL, Los Alamos National Laboratory (2008) Investigation Report for Bayo Canyon Aggregate Area. Los Alamos National Laboratory Report LA-UR-08-1134. 
[7] LANL, Los Alamos National Laboratory (2009) Cañada del Buey Investigation Report. Los Alamos National Laboratory Report LA-UR-4668.

[8] LANL, Los Alamos National Laboratory (2006) Mortandad Canyon Investigation Report. Los Alamos National Laboratory Report LA-UR-06-6752.

[9] Becker, P.H. (2003) Biomonitoring with Birds. Trace Metals and Other Contaminants in the Environment, 6, 677-736. https://doi.org/10.1016/S0927-5215(03)80149-2

[10] Ackerman, J.T., Eagles-Smith, C.A., Herzog, M.P. and Hartman, C.A. (2016) Maternal Transfer of Contaminants in Birds: Mercury and Selenium Concentrations in Parents and Their Eggs. Environmental Pollution, 210, 145-154. https://doi.org/10.1016/j.envpol.2015.12.016

[11] Dauwe, T., Janssens, E., Bervoets, L., Blust, R. and Eens, M. (2005) Heavy-Metal Concentrations in Female Laying Great Tits (Parus major) and Their Clutches. Archives of Environmental Contamination and Toxicology, 49, 249-256. https://doi.org/10.1007/s00244-003-0209-z

[12] Hashmi, M.Z., Abbasi, N.A., Tang, X. and Malik, R.N. (2015) Eggs as a Biomonitor of Heavy Metals in Soil. In: Sherameti, I., and Varma, A., Eds., Heavy Metal Contamination of Soils, Springer International Publishing Switzerland, New York, 127-143. https://doi.org/10.1007/978-3-319-14526-6_7

[13] Boncompagni, E., Muhammad, A., Jabeen, R., Orvini, E., Gandini, C., Sanpera, C. Ruix, X. and Fasola, M. (2003) Egrets as Monitors of Trace-Metal Contamination in Wetlands of Pakistan. Archives of Environmental Contamination and Toxicology, 45, 399-406. https://doi.org/10.1007/s00244-003-0198-y

[14] Furness, R. (1993) Birds as Monitors of Pollutants. In: Furness, R. and Greenwood, J., Eds., Birds as Monit Environ Chang, Springer, London, 86-143. https://doi.org/10.1007/978-94-015-1322-7_3

[15] Nyholm, N. (1994) Heavy Metal Tissue Levels, Impact on Breeding and Nestling Development in Natural Populations of Pied Flycatcher (Aves) in the Pollution Gradient from a Smelter. In: Donker, M.H., Eijsackers, H. and Heimbach, F., Eds., Ecotoxicology of Soil Organisms, Lewis Publishers, Boca Raton, 373-382.

[16] Yogui, G.T. and Sericano, J.L. (2009) Levels and Pattern of Polybrominated Diphenyl Ethers in Eggs of Antarctic Seabirds: Endemic versus Migratory Species. Environmental Pollution, 157, 975-980. https://doi.org/10.1016/j.envpol.2008.10.016

[17] Heinz, G. (1974) Effects of Low Dietary Levels of Methyl Mercury on Mallard Reproduction. Bulletin of Environmental Contamination and Toxicology, 11, 386-392. https://doi.org/10.1007/BF01684947

[18] Heinz, G. (1975) Effects of Methylmercury on Approach and Avoidance Behavior of Mallard Ducklings. Bulletin of Environmental Contamination and Toxicology, 13, 554-564. https://doi.org/10.1007/BF01685179

[19] Wiemeyer, S.N. and Hoffman, D.J. (1996) Reproduction in Eastern Screech-Owls Fed Selenium. Journal of Wildlife Management, 60, 332-341. https://doi.org/10.2307/3802232

[20] Gochfeld, M. and Burger, J. (1998) Temporal Trends in Metal Levels in Eggs of the Endangered Roseate Tern (Sterna dougallii) in New York. Environmental Research, 77, 36-42. https://doi.org/10.1006/enrs.1997.3802

[21] Tsipoura, N., Burger, J., Feltes, R., Yacabucci, J., Mizrahi, D., Jeitner, C. and Gochfeld, M. (2008) Metal Concentrations in Three Species of Passerine Birds Breeding in the Hackensack Meadowlands of New Jersey. Environmental Research, 107, 218-228. https://doi.org/10.1016/j.envres.2007.11.003 
[22] Swaileh, K.M. and Sansur, R. (2006) Monitoring Urban Heavy Metal Pollution Using the House Sparrow (Passer domesticus). Journal of Environmental Monitoring, 8, 209-213. https://doi.org/10.1039/B510635D

[23] Mora, M.A. (2003) Heavy Metals and Metalloids in Egg Contents and Eggshells of Passerine Birds from Arizona. Environmental Pollution, 125, 393-400. https://doi.org/10.1016/S0269-7491(03)00108-8

[24] Dauwe, T., Bervoets, L., Blust, R., Pinxten, R. and Eens, M. (1999) Are Eggshells and Egg Contents of Great and Blue Tits Suitable as Indicators of Heavy Metal Pollution? Belgian Journal of Zoology, 129, 439-447.

[25] Fair, J.M., Myers, O.B. and Ricklefs, R.E. (2003) Immune and Growth Response of Western Bluebirds and Ash-Throated Flycatchers to Soil Contaminants. Ecolological Applications, 13, 1817-1829. https://doi.org/10.1890/02-5058

[26] The Cornell Lab of Ornithology (2015) Ash-Throated Flycatcher. https://www.allaboutbirds.org/guide/Ash-throated_Flycatcher/id

[27] The Cornell Lab of Ornithology (2015) Western Bluebird. https://www.allaboutbirds.org/guide/Western_Bluebird/id

[28] Yard, H., Van Riper, C., Brown, B.T. and Kearsley, M.J. (2004) Diets of Insectivorous Birds along the Colorado River in Grand Canyon, Arizona. Condor, 106, 106-115. https://doi.org/10.1650/7242

[29] Audubon (2016) Ash-Throated Flycatcher. http://www.audubon.org/field-guide/bird/ash-throated-flycatcher

[30] Fair, J., Hanelt, B. and Burnett, K. (2010) Horsehair Worms (Gordius robustus) in Nests of the Western Bluebird (Sialia mexicana): Evidence for Anti-Predator Avoidance? Journal of Parasitology, 96, 429-430.

[31] Mock, P.J., Khubesrian, M. and Larcheveque, D.M. (1991) Energetics of Growth and Maturation in Sympatric Passerines That Fledge at Different Ages. Auk, 108, 34-41.

[32] Fresquez, P.R., Gaukler, S.M., Hansen, L.A., Hathcock, C.D., Keller, D. and McNaughton, M. (2015) Ecosystem Health. Los Alamos National Laboratory Report LA-UR-16-26788.

[33] U.S. Climate Data (2015) Climate Los Alamos-New Mexico. http://www.usclimatedata.com/climate/los-alamos/new-mexico/united-states/usnm $\underline{0179}$

[34] McKown, B., Koch, S., Balice, R. and Neville, P. (2003) Land Cover Map for the Eastern Jemez Region. Los Alamos Laboratory Report LA-UR-14029. https://doi.org/10.2172/818636

[35] Fair, J. and Myers, O. (2002) Early Reproductive Success of Western Bluebirds and Ash-Throated Flycatchers: A Landscape-Contaminant Perspective. Environmental Pollution, 118, 321-330. https://doi.org/10.1016/S0269-7491(01)00302-5

[36] Custer, T.W., Custer, C.M., Johnson, K.M. and Hoffman, D.J. (2008) Mercury and Other Element Exposure to Tree Swallows (Tachycineta bicolor) Nesting on Lostwood National Wildlife Refuge, North Dakota. Environmental Pollution, 155, 217-226. https://doi.org/10.1016/j.envpol.2007.12.003

[37] Brasso, R.L., Abdel Latif, M.K. and Cristol, D.A. (2010) Relationship between Laying Sequence and Mercury Concentration in Tree Swallow Eggs. Environmental Toxicology and Chemistry, 29, 1155-1159. https://doi.org/10.1002/etc.144

[38] Jackson, A.K., Evers, D.C., Etterson, M.A., Condon, A.M., Folsom, S.B., Detweilier, J., Schmerfeld, J. and Cristol, D.A. (2011) Mercury Exposure Affects the Reproduc- 
tive Success of a Free-Living Terrestrial Songbird, the Carolina Wren (Thryothorus ludovicianus). Auk, 128, 759-769. https://doi.org/10.1525/auk.2011.11106

[39] Bryan, A.L., Hopkins, W.A., Baionno, J.A. and Jackson, B.P. (2003) Maternal Transfer of Contaminants to Eggs in Common Grackles (Quiscalus quiscala) Nesting on Coal Fly Ash Basins. Archives of Environmental Contamination and Toxicology, 45, 273-277. https://doi.org/10.1007/s00244-002-0212-9

[40] Burger, J., Woolfenden, G.E. and Gochfeld, M. (1999) Metal Concentrations in the Eggs of Endangered Florida Scrub-Jays from Central Florida. Archives of Environmental Contamination and Toxicology, 37, 385-388. https://doi.org/10.1007/s002449900529

[41] Burger, J., Bowman, R., Woolfenden, G.E. and Gochfeld, M. (2004) Metal and Metalloid Concentrations in the Eggs of Threatened Florida Scrub-Jays in Suburban Habitat from South-Central Florida. Science of the Total Environment, 328, 185-193. https://doi.org/10.1016/j.scitotenv.2004.01.030

[42] Custer, T.W., Custer, C.M., Larson, S. and Dickerson, K.K. (2002) Arsenic Concentrations in House Wrens from Whitewood Creek, South Dakota, USA. Bulletin of Environmental Contamination and Toxicology, 68, 517-524. https://doi.org/10.1007/s001280285

[43] Custer, T.W. Dummer, P.M., Custer, C.M., Li, A.U., Warburton, D., Melancon, M.J., Hoffman, D.J., Matson, C.W. and Bickham, J.W. (2007) Water Level Management and Contaminant Exposure to Tree Swallows Nesting on the Upper Mississippi River. Environmental Monitiroing and Assessment, 133, 335-345. https://doi.org/10.1007/s10661-006-9588-8

[44] Helsel, D. (2012) Computing Summary Statistics and Totals in Statistics for Censored Data Using Minitab and R. In: Helsel, D., Ed., Statistics for Censored Environmental Data Using Minitab and R, 2nd Edition, Wiley, Hoboken, 62-98.

[45] Helsel, D. (2012) Comparing Two Groups. In: Helsel, D., Ed., Statistics for Censored Environmental Data Using Minitab and $R$, 2nd Edition, Wiley, Hoboken, 153-193.

[46] Stoewsand, G.S., Bache, C.A., Gutenmann, W.H. and Lisk, D.J. (1986) Cocentration of Cadmium in Coturnix Quail Fed Earthworms. Journal of Toxicology and Envrionmental Health, 18, 369-376. https://doi.org/10.1080/15287398609530878

[47] Leach, R., Wang, K. and Baker, D. (1979) Cadmium and the Food Chain: The Effect of Dietary Cadmium on Tissue Composition in Chicks and Laying Hens. The Journal of Nutrition, 109, 437-443. https://doi.org/10.1093/jn/109.3.437

[48] Pattee, O.H. (1984) Eggshell Thickness and Reproduction in American Kestrels Exposed to Chronic Dietary Lead. Archives of Environmental Contamination and Toxicology, 13, 29-34. https://doi.org/10.1007/BF01055643

[49] White, D.H. and Dieter, M.P. (1978) Effects of Dietary Vanadium in Mallard Ducks. Journal of Toxicology and Envrionmental Health, 4, 43-50. https://doi.org/10.1080/15287397809529643

[50] Schwarzbach, S.E., Albertson, J.D. and Thomas, C.M. (2006) Effects of Predation, Flooding, and Contamination on Reproductive Success of California Clapper Rails (Rallus Longirostris Obsoletus) in San Francisco Bay. Auk, 123, 45-60. https://doi.org/10.1642/0004-8038(2006)123[0045:EOPFAC]2.0.CO;2

[51] Seiler, R.L. and Skorupa, J.P. (2001) National Irrigation Water Quality Program Data-Synthesis Data Base. Carson City, NV.

[52] Shacklette, H. and Boerngen, J. (1984) Element Concentrations in Soils and Other Surficial Materials of the Conterminous United States. US Geological Survey Pro- 
fessional Paper 1270.

[53] Clark, F. and Washington, H. (1924) The Composition of the Earth's Crust. USGS Professional Paper 127, Washington DC.

[54] USGS (2016) Bandelier Tuff; Jemez Mountains Area Only. http://mrdata.usgs.gov/geology/state/sgmc-unit.php?unit=NMQbt\%253B0

[55] World of Earth Science (2003) Rhyolite. http://www.encyclopedia.com/topic/rhyolite.aspx

[56] Fresquez, P.R. (2012) Soil Monitoring. Los Alamos National Laboratory Report ERID-250040.

[57] Heinz, G.H., Hoffman, D.J. and Gold, L.G. (1989) Impaired Reproduction of Mallards Fed an Organic Form of Selenium. The Journal of Wildlife, 53, 418-428. https://doi.org/10.2307/3801145 